\title{
Growth parameters estimates for a small fish of the Pantanal, Brazil: Moenkhausia dichroura (Characiformes; Characidae)
}

\author{
Cunha, NL. ${ }^{\mathrm{a} *}$, Catella, AC. ${ }^{\mathrm{b}}$ and Kinas, $M A .^{\mathrm{a}}$

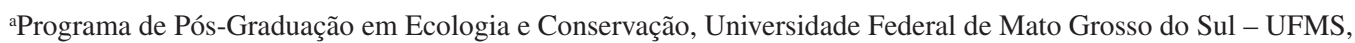 \\ CEP 79070-900, Campo Grande, MS, Brazil \\ 'EMBRAPA - PANTANAL, Rua 21 de Setembro, 1880, CEP 79320-900, Corumbá, MS, Brazil \\ *e-mail: nicolaycunha@gmail.com
}

Received March 14, 2005 - Accepted March 28, 2005 - Distributed May 31, 2007

(With 2 figures)

\begin{abstract}
Growth parameters were estimated for Moenkhausia dichroura (Kner, 1858) (Characiformes, Characidae), a smallsized and very abundant fish of the Pantanal lentic habitats commonly known as "pequira ". A method based on the length frequencies distribution and the ELEFAN I routine from the FISAT program were used. The fish were collected in the Baia da Onça, an oxbowlake of the sub-region Pantanal of Aquidauana, Mato Grosso do Sul, Brazil, from June to December 1988. The standard length of the captured fishes ranged from 29 to $76 \mathrm{~mm}$ with an average of $53 \mathrm{~mm}$. The estimated growth parameters were $\mathrm{L}_{\infty}=81 \mathrm{~mm}$ (standard length), $\mathrm{k}=0.85$ year $^{-1}, \mathrm{C}=0.89, \mathrm{WP}=0.6(\mathrm{Rn}=0.285)$. The WP indicated that growth reduction occurred in July, when the lowest temperature of the year was registered. The growth curve showed that captured individuals belonged to three cohorts. The obtained results seem robust and quite compatible with the biology of the fish and its adjustment to the environment. $M$. dichroura, in spite of not being a direct fishing interest, is an important species in terms of its ecological aspects, due to its abundance and high growth rate, and as a great food source for aquatic organisms and specially for larger fish of economic value. Considering the information gap about small fish, the parameters estimated for pequira constitute a comparison base for other growth studies of small-sized fish species of tropical environments.
\end{abstract}

Keywords: pequira, Tetragonopterinae, Aquidauana River, lenth friquencie, ELEFAN.

\section{Estimativa dos parâmetros de crescimento para um pequeno peixe do Pantanal, Brasil: Moenkhausia dichroura (Characiformes; Characidae)}

\begin{abstract}
Resumo
Neste estudo foram estimados os parâmetros de crescimento para Moenkhausia dichroura (Kner, 1858) (Characiformes, Characidae), um peixe de pequeno porte e muito abundante nos ambientes lênticos do Pantanal, onde é conhecido, vulgarmente, como "pequira". Para a estimativa dos parâmetros, foi utilizada uma metodologia baseada na distribuição mensal das freqüências de comprimento por meio da rotina ELEFAN I do programa FISAT. Os peixes foram coletados na Baía da Onça, uma lagoa do Pantanal do rio Aquidauana, Mato Grosso do Sul - Brasil, entre junho e dezembro de 1988. O comprimento dos exemplares capturados variou de 29 a $76 \mathrm{~mm}$ com média igual a $53 \mathrm{~mm}$. Os melhores ajustes obtidos para os parâmetros de crescimento foram $\mathrm{L} \infty=81 \mathrm{~mm}$ (comprimento padrão), $\mathrm{k}=0.85 \mathrm{ano}^{-1}, \mathrm{C}=0.89 \mathrm{e}$ $\mathrm{WP}=0.6(\mathrm{Rn}=0.285)$. O valor de WP indicou que a redução do crescimento ocorreu em julho, quando foram registradas as menores temperaturas do ano. A curva de crescimento obtida indicou que foram capturados indivíduos pertencentes a três cortes. Os resultados obtidos parecem robustos e bastante compatíveis com a biologia do peixe e seu ajuste ao ambiente. $M$. dichroura, apesar de não ser de interesse direto para a pesca, é uma espécie importante sob o ponto de vista ecológico, em função de sua abundância e elevada taxa de crescimento corporal, constituindo uma grande fonte de alimento para os demais organismos aquáticos e, sobretudo, para os peixes maiores de valor econômico. Em função da carência de informações, os parâmetros aqui estimados para a pequira constituem uma base de comparação para outros estudos sobre o crescimento de espécies de peixes de pequeno porte nos ambientes tropicais.
\end{abstract}

Palavras-chave: pequira, Tetragonopterinae, rio Aquidauana, freqüência de comprimento, ELEFAN. 


\section{Introduction}

The floodplains are highly productive environments and evidence important ecological activities in the continents (Goulding, 1980, Bayley and Petrere, 1989). They constitute spawning and growth areas for lots of fishes as a result of their habitat diversity, supplying food and shelter against predators (Goulding, 1979; Lowe-McConnel, 1987). The Pantanal is an extensive alluvial plain located at the centre of South America, with a flooded area of about $140,000 \mathrm{~km}^{2}$ (BRASIL, 1997), with the River Paraguay running slowly northsouth as the main drainage axis. This singular region encompasses a diversity of flora and fauna, that combine in a complex hydrologic system, formed by different kinds of aquatic habitats such as rivers, corixos (intermittent creeks), ponds of different types and swamps (Mourão, 1989). As in other tropical wetlands, annual flooding is the main ecological phenomenon (Hamilton et al., 1996, Catella and Petrere, 1996), of fundamental importance for the ichthyofauna because the extension of the annual flood area and permanence time of waters in the field controls the habitat and food availability for the fish, conditioning their abundance (Catella, 1992).

Fish probably constitute one of the largest living nutrient and energy resources for the Pantanal ecosystem (Catella, 1992). According to Coutinho et al. (1997), 32 bird species were found, among more than 600 registered for the region are ichthyofagous, as well as three mammal species and seven snakes, besides the Pantanal alligator (Caiman crocodilus), a very abundant reptile which ingests fish in all phases of its life (Santos, 1997). Although fish represent a quite diversified group in the Pantanal plain, where more than 260 species have been listed (Britski et al., 1999), the ecosystem is still little studied regarding fish (Machado, 2003). Knowledge on fish species ecology (as well as in every tropical region) are mostly concentrated on those of larger sizes, due to their commercial interest (Lowe-McConnel, 1987).

Thus, the available knowledge about species biology, populations dynamics and fish community structure of the Pantanal constitute a set of important tools to subsidize not only the sustainable exploration of the fishing resources, but also the regional development policy options, allowing to evaluate and foresee the possible effects on the ecosystem of the different options. In that sense, this study aims to contribute by estimating the growth parameters for Moenkhausia dichroura (Kner, 1858) (Characiformes, Characidae), a small-sized fish commonly known as "pequira" which is not exploited by the fisheries, but surely plays an important ecological role, since it is very abundant in lentic habitats of the region. The method used was based on the monthly length frequencies distribution of the individuals collected in the Baia da Onça, a Pantanal lake, during the period in which the lake remained disconnected from the river.

\section{Material and Methods}

\subsection{Study area}

This study was realized in the Baia da Onça $\left(20^{\circ} 02\right.$ ' 14.639' $\mathrm{S}$ and $55^{\circ} 57^{\prime}$ 55.994” $\left.\mathrm{W}\right)$, an oxbowlake located on the right margin of the Aquidauana river, in the sub-region Pantanal of Aquidauana, about $60 \mathrm{~km}$ down river of Aquidauana city, Mato Grosso do Sul State, Brazil. The horseshoe form of the lake arises from the $\mathrm{u}$-shaped bends characteristic of the river in this area, and it joins the river in the beginning of the flood season (December/January) and then becomes isolated again when the water level falls (April/May). Baia da Onça is a perennial lake, which keeps the water quality compatible for fish life during the whole year, as observed in Ferreira et al. (1990). The area of the lake was evaluated in 10.4 ha during the drought period, with an average depth of $1.17 \mathrm{~m}$ and maximum depth of $3.20 \mathrm{~m}$, maximum length of $1672 \mathrm{~m}$ and an average width of $62.1 \mathrm{~m}$ (Catella, 1992).

In the plain, more than $40 \%$ of the Pantanal fish species are Characiformes (Britski et al., 1997), which include many small size species such as Moenkhausia dichroura, commonly known as "pequira", as well as several other small fishes. According to Pouilly et al. (2003), the species have bento-pelagic habits, being usually found in the Amazon and Paraguay Basins. Catella (1992) studied the fish community structure and feeding of Baia da Onça. He verified that $M$. dichroura was the most abundant species in number and the second most abundant in biomass among more than 70 community species, feeding mainly on zooplankton organisms (Copepoda and Cladocera).

\subsection{Sampling procedure and data analysis}

Samplings were accomplished monthly from June to December 1988, with duration from one to three days. Fish were caught using two types of gear: a 66-m dragnet and a 33-m mini-purse-seine net, both with stretched mesh size of $13.3 \mathrm{~mm}$ and $6.4 \mathrm{~m}$ high. The dragnets were used in the drier months when margins were available for trawling, and the mini purse-seine was used in the high water period, because it allows the catching of fish in the lake at that period. The individuals of $M$. dichroura collected with both nets were considered as a unique sample. The fish caught were cooled in the field and taken to the laboratory, where they were kept frozen, then defrosted only at the biometry time.

The standard lengths (Ls) - measures in millimeters from the tip of the muzzle to the end of the caudal peduncle - were taken from at least 200 specimens each month. The total length (Lt) - in millimeters from the tip of the muzzle to the end of the caudal fin -, was also measured and the total weight $(\mathrm{Wt})$ in grams was obtained using an electronic balance with $0.01 \mathrm{~g}$ precision. The relation between total length and standard length was adjusted using the Pearson linear regression, obtaining the linear equation: $\mathrm{Lt}=\mathrm{a}+\mathrm{b}$ Ls. The 
total weight and standard length relation was adjusted by linear regression of the natural logarithms of these variables which were afterwards converted to the exponential model: $\mathrm{Wt}=\mathrm{a} \mathrm{Ls}^{\mathrm{b}}$.

The growth parameters of the von Bertalanffy model presented by Somers (1988) were estimated from the monthly distribution of standard length (Ls) of $M$. dichroura, using the ELEFAN I routine of the program FISAT (Gayanilo et al. 1997), according to the equation:

$\mathrm{L}_{\mathrm{t}}=\mathrm{L} \infty\left[1-\mathrm{e}^{-\mathrm{k}(\mathrm{t}-\mathrm{to})-(\mathrm{CK} / 2 \pi)[\sin 2 \pi(\mathrm{t}-\mathrm{ts})-\sin 2 \pi(\mathrm{to}-\mathrm{ts})]}\right]$

where: $\mathrm{L} \infty=$ asymptotic length $(\mathrm{mm}) ; \mathrm{K}=$ coefficient growth $\left(\right.$ year $\left.^{-1}\right) ; \mathrm{t}=$ relative age; to $=$ nominal age when the length is zero; $\mathrm{C}=$ growth oscillation parameter; and $\mathrm{WP}=$ Winter Point $=\mathrm{ts}+0.5$ year.

In order to accomplish the analysis, the fish were separated in two standard length classes with interval distributions of 1 and $2 \mathrm{~mm}$, which were analyzed separately to compare the results. FISAT still supplies the growth performance index $(\phi)$ proposed by Pauly and Munro (1984) $\left(\phi=\log _{10}(\mathrm{~K})+2 \log _{10}(\mathrm{~L} \infty)\right)$, which allows the comparison of the estimated parameters with those of other species or groups philogenetically related.

\section{Results}

The standard lengths were measured of 1602 M. dichroura specimens captured varying from 29 to $76 \mathrm{~mm}$ and of $53.0 \mathrm{~mm}$ average. A polymodal length frequencies distribution was obtained, however, this was asymmetric and truncated to the left side in the region of the smaller lengths (Figure 1).

The total weight $(\mathrm{Wt})$ and the total length $(\mathrm{Lt})$ of pequira were estimated in relation to the standard length (Ls), respectively by the following equations:

$\mathrm{W}_{\mathrm{t}}=1.55 \times 10^{-5} \times \mathrm{Ls}^{3.045}$

$(\mathrm{n}=1607, \mathrm{r}=0.948, \mathrm{P}<0.001)$

$\mathrm{L}_{\mathrm{t}}=1.165 \mathrm{Ls}+5.190$

$(\mathrm{n}=581, \mathrm{r}=0.978, \mathrm{P}<0.001)$

The best set of growth parameters obtained for Moenkhausia dichroura were $\mathrm{L} \infty=81 \mathrm{~mm}, \mathrm{k}=0.85$ year $^{-1}$, $\mathrm{C}=0.89$, WP $=0.6$ and $\phi=3.75$. These values were obtained for both distributions of 1 and $2 \mathrm{~mm}$ class intervals, and the best adjustment was $\mathrm{Rn}=0.285$ to the last one. $\mathrm{C}$ value was close to 1 , which indicates that the species growth is subject to an expressive oscillation along the year. The WP value indicates that the smaller growth rate occurred in July, 1988. The growth curve indicated that the captured individuals belong to three cohorts and that the recruitment occurred in mid-October (Figure 2). Using biometry relations, a $M$. dichroura specimen with $\mathrm{Ls}=81 \mathrm{~mm}$, measures $\mathrm{Lt}=99.5 \mathrm{~mm}$ and weighs $\mathrm{Wt}=10.03 \mathrm{~g}$.

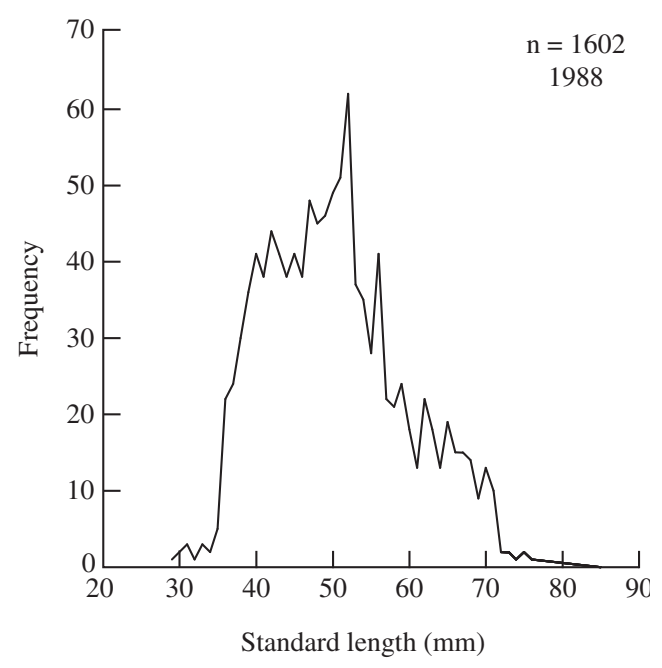

Figure 1. Frequency distribution of standard length of Moenkhausia dichroura captured in Baia da Onça, a Pantanal lake, Mato Grosso do Sul (Brazil).

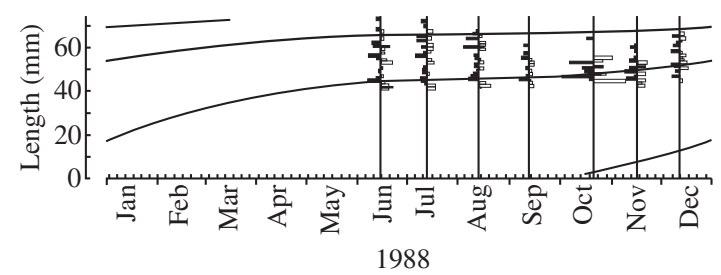

Figure 2. Frequency distribution of standard length and growth curve estimated for Moenkhausia dichroura captured in Baia da Onça, a Pantanal lake, Mato Grosso do Sul (Brazil) for 1988.

\section{Discussion}

Fish life strategies are the result of natural selection that aim to produce the biggest number of descendents that will survive until maturity under the conditions imposed by the biotope (Lowe-McConnell, 1987). Thus, the fact that Moenkhausia dichroura is the more abundant fish species in number in Baia da Onça is an indicator of its biological success, reflecting an adjustment among the species demands and the environmental characteristics. A high growth rate for $M$. dichroura $\left(\mathrm{k}=0.85\right.$ year $\left.^{-1}\right)$ was estimated, as generally occurs for small-sized species, which also tend to present high rates of natural mortality (Pauly, 1980), characterizing itself as $r$-strategists. These estimates seem compatible with Benine's (2004) consideration of $M$. dichroura as a high resilience species that could double its population size in less than 15 months.

The Baia da Onça is a perennial pond, which is annually connected to the river and, therefore, is subject to rising water flowing from the river during the floods. The adjustment of the biological characteristics of $M$. dichroura to the environmental characteristics of the Baia da Onça corroborates Laë's (1997) conclusions about the fish communities in African lakes. The author 
verified that the $r$-strategist fish - the ones that evidence fast growth, precocious maturity and high resilience - present a relative advantage in the regions where the annual flood pulse occurs. These fish are able to establish themselves more quickly in the water bodies and are more capable of enduring the part of the year that offers fewer resources, as compared to the k-strategists species, according to Laë (1997). A similar situation was described by Junk et al. (1997) for the Amazon plain, verifying that the flood pulse promotes the increase of the nutrients necessary for the $r$-strategist fish.

The growth performance index value ( $\left.\phi^{\prime}\right)$ is the result of the relation between $\mathrm{L} \infty$ and $\mathrm{k}$ and should present close values for species phylogenetically related (Gayanillo et al., 1997). Thus, its values constitute a reference to validate the growth parameters estimate. However, only little information about small-sized species growth phylogenetically close to $M$. dichroura is available in the literature. Capistrano-Santana et al. (2004), using ELEFAN I, estimated the growth parameters for "saicanga" Roeboides paranensis, a small-sized Characidae, which was captured during the same sampling carried out for this study in Baia da Onça. Due to the lack of biological information on the species, the authors chose not to present a single conclusive answer, but three sets of parameters that are shown in Table 1 . It is observed that the growth performance index values obtained for $M$. dichroura differed by just $1.6 \%$ from those of sets 1 and 3 and differed by $2.9 \%$ from set 2 of $R$. paranensis. The $M$. dichroura $\mathrm{C}$ and WP values were close to those obtained in set 2 of $R$. paranesis (with an intermediary $\mathrm{Rn}$ value), that could suggest growth reduction for both species in July.

The polymodal aspect of the length frequency distribution of $M$. dichroura indicates the presence of several cohorts that are compatible with a well-established species population in Baia da Onça. The truncated distribution on the left side is probably due to the net selectivity: the $13.3 \mathrm{~mm}$ meshes let most of the young individuals smaller than around $35 \mathrm{~mm}$ of the standard length escape.

The WP value corresponded to July, the coldest month in 1988, with a monthly average temperature of $18.1^{\circ} \mathrm{C}$ registered at the Climatological Station of Fazenda Nhumirim in the sub-region Pantanal of Nhecolândia (Embrapa, 1997). Therefore, this indicates that the pequira growth reduction is related to the decrease in temperature. In fact, under controlled experiment conditions,

Table 1. Values of L $\infty, \mathrm{K}, \mathrm{C}, \mathrm{WP}, \phi$ ' and RN estimated for Moenkhausia dichroura in this study compared to three sets of parameters estimated for Roeboides paranensis by Capistrano-Santana et al. (2004).

\begin{tabular}{lclccccc}
\hline & Set & L $\infty$ & K & C & WP & RN & $\phi$ \\
\hline M. dichroura & - & 81 & 0.85 & 0.89 & 0.6 & 0.285 & 3.75 \\
R. paranensis & 1 & 91.6 & 0.77 & 0.0 & 0.0 & 0.148 & 3.81 \\
& 2 & 92 & 0.52 & 0.85 & 0.6 & 0.173 & 3.64 \\
& 3 & 91.6 & 0.77 & 0.53 & 0.91 & 0.180 & 3.81 \\
\hline
\end{tabular}

it is observed that the decrease in temperature can delay the growth of the fish (Lorenzen, 1996; Halls et al., 1999). The Moekhausia dichroura growth curve indicated that the recruitment - the entrance of a new cohort in the population - would occur in the middle of October, but there is no available information about the species reproduction. However, this period does not agree with the biology of the majority of Baia da Onça fish. They would be maturing their gonads at the end of the drought season (September/November) to spawn in the floods (December/January), when the renewed river waters invade the lake (Catella, 1992). Another possibility to be considered is some interference of the selection of capture devices on the apparent recruitment period. Regarding this aspect, Catella (1992) observed an increase of the lake's fish biomass from July to August, 1988. The author attributed that to the small specimen growth that escaped before and, only in August, became big enough to be recruited for the nets band selectivity. This fact could introduce some bias in establishing the recruitment period.

In spite of not being a direct fishing interest, Moekhausia dichroura is an important species in terms of ecological aspects, due to its abundance and high growth rate, as a great food source for aquatic organisms and specially for the larger fish of economic value. The present study demonstrates that Baia da Onça, together with other perennial lakes of the Pantanal with similar characteristics constitute adequate habitats for growth and maintenance of M.dichroura populations. Moreover, regarding to the lack of information, the set of parameter estimates for pequira constitutes a comparison base for other growth studies of small-sized fish of tropical environments.

Acknowledgments - To the PG Ecology and Conservation Program - UFMS to provide the field course Ecology of Freshwater Fishes. To Embrapa Pantanal and UFMS - PG Ecology and Conservation Program for the logistic support and facilities; to the group of colleagues for the productive interaction that was established; to the employees of UFMS Pantanal Base, for the whole support during the study; to CNPq for the Master's scholarship conceded to ACC at UNICAMP (data were collected during the research for the Master's); and to Denise Justino da Silva (Embrapa - Pantanal) for the English revision of the manuscript.

\section{References}

BAYLEY, PB. and PETRERE Jr., M., 1989. Amazon fisheries: assessment methods, current status and management options. In DODGE, DP. (ed.), Proceedings of the International Large River Symposium. Can. Spec. Publ. Fish. Aquat. Sci., vol. 106, p. 385-398.

BENINE, RC., 2004. Fish Base In: www. fishbase.org/ Moenkhausia_dichroura.

BRASIL. 1997. Ministério do Meio Ambiente dos Recursos Hídricos e da Amazônia Legal. Plano de Conservação da Bacia do Alto Paraguai (Pantanal) - PCBAP: análise integrada e prognóstico da Bacia do Alto Paraguai. Brasília, v. 3. 369 p., anexos. Programa Nacional do Meio Ambiente. Projeto Pantanal. 
BRISTSKI, HA., SILIMON, KZ. DE S. and LOPES, BS., 1999, Peixes do Pantanal, Manual de Identificação. Brasília EMBRAPA - SPI, Corumbá: EMBRAPA - CPAP. 184p.

CAPISTRANO-SANTANA, A., ALMEIDA, RS., ÁVILA, RW. and CATELLA, AC., 2004. Estimativa dos parâmetros de crescimento de Roeboides paranensis: diferentes respostas para uma mesma pergunta. In 4 Simpósio sobre Recursos Naturais e Socio-Econômicos do Pantanal - Sustentabilidade Regional, 2004, Corumbá, MS: Embrapa Pantanal, (CD-ROM).

CATELLA, AC., 1992. Estrutura da comunidade e alimentação dos peixes da Baía da Onça, uma Lagoa do Pantanal do Rio Aquidauana - MS. 215p. (Dissertação de Mestrado) - Campinas, UNICAMP, São Paulo.

CATELlA, AC. and PETRERE, M., 1996. Feeding patterns in a fish community of Baia da Onça a floodplain lake of the Aquidauana River, Pantanal, Brazil. Fisher. Manag. and Ecol., vol. 3, no. 3, p. 229-237.

COUTINHO, ME., CAMPOS, Z., MOURÃO, G. and MAURO, R. 1997. Vertebrados Terrestres e Semi-aquáticos. In Brasil. Ministério do Meio Ambiente, dos Recursos Hídricos e da Amazônia Legal. Plano de Conservação da Bacia do Alto Paraguai (Pantanal) - PCBAP. Diagnóstico dos meios físico e biótico: meio biótico. Brasília, vol. 2, no. 3, p. 183-323.

EMBRAPA. AGROMETEOROLÓGICO: 1986-1996 (Fazenda Nhumirim). Corumbá: Embrapa-CPAP, 1997. p.81 (EmbrapaCPAP, Boletim Agrometeorológico, 3).

FERREIRA, CJA., CATELLA, AC. and ALMEIDA, LC. 1990. Baía da Onça: parâmetros físicos, químicos e biológicos durante a fase de isolamento do rio Aquidauana, Pantanal MatoGrossense. In III Congresso Brasileiro de Limnologia. Resumos. Porto Alegre.

GAYANILO, JR., FC. SPARRE, P. and PAULY, D., 1997. The FAO-ICLARM Stock Assesment Tools (FISAT) User's guide. FAO Computerized information Series (Fisheries) Rome, vol. 8, p. 262.

GOULDING, M., 1979. Ecologia da Pesca do rio Madeira. Belém: $\mathrm{CNPq} / \mathrm{INPA}, 172 \mathrm{p}$.

-, 1980. The Fishes and the Forest: Explorations in Amazonian Natural History. Los Angeles: University of California Press, 280p.

HAMILTON, SK., SIPPEL, SJ. and MELACK, JM., 1996. Inundation patterns in the Pantanal wetland of South America determined from passive microwave remote sensing. Arch. Hydrobiol., vol. 137, no. 1, p. 1-23.
HALLS, AS., HOGGARTH, DD. and DEBNATH, K., 1999. Impacts of hydraulic engineering on the dynamics and production potential of floodplain fish populations in Bangladesh. Fish. Manag. and Ecol., vol. 6, p. 261-285.

JUNK, WJ., SOARES, MGM. and SAINT-PAUL, U., 1997. The Fish. In JUNK, WB. (ed) The central Amazon Floodplain Ecology of a Pulsing System. Ecolog. Stud. 126, Berlin: Springer, 525p.

LAË, R., 1997. Does overfishing lead to a decrease in catches and yields? An example of two West African coastal lagoons. Fish. Manag. and Ecol., vol. 4, p. 149-164.

LORENZEN, K., 1996. A simple von Bertalanffy model for density dependent growth in extensive aquaculture, with an application to common carp (Cyprinus carpio). Aquacul., vol. 142 , p. 191-205.

LOWE-McCONNELL, R., 1987. Ecological Studies in Tropical Fish Communities. Cambridge: Cambridge University Press. 382p.

MACHADO, FA., 2003. História natural de peixes do Pantanal: com destaque em hábitos alimentares e defesa contra predadores. (Dissertação de Mestrado) - UNICAMP, Campinas, SP.

MOURÃO, GM., 1989. Limnologia comparativa de três lagoas (Duas "baías" e uma "salina") do Pantanal da Nhecolândia, MS. 135p. (Dissertação de Mestrado) - Ciências Biológicas, Universidade Federal de São Carlos.

PAULY, D., 1980. On the interrelationships between natural mortality, growth parameters and mean environmental temperature in 175 fish stocks. J. Cons. CIEM, vol. 39, no. 3, p. $175-92$.

PAULY, D. and JL. MUNRO, 1984. Once more on the comparison of growth in fish and invertebrates. ICLARM Fishbyte, vol. 2, no. 1, p. 21.

POUILLY, M., LINO, F., BRETENOUX, JG., and ROSALES C., 2003. Dietary-morphological relationships in a fish assemblage of the Bolivian Amazonian floodplain, Jour. of Fish Biol., vol. 62 , no. 5 , p. $1137-1158$.

SANTOS, SA., 1997. Dieta e nutrição de crocodilianos. Corumbá: EMBRAPA-CPAP. 59p. (EMBRAPA-CPAP Documentos, 20).

SOMERS, IF., 1988. On a seasonally osclillating growth function. ICLARM Fishbyte. vol. 7, no. 2, p. 13-14. 
